\title{
Interactive comment on "Projecting Antarctica's contribution to future sea level rise from basal ice-shelf melt using linear response functions of 16 ice sheet models (LARMIP-2)" by Anders Levermann et al.
}

\section{Anders Levermann \\ anders.levermann@pik-potsdam.de}

Received and published: 12 July 2019

Dear reviewer,

Thank you for taking on the review and for your comments. We will be addressing them in our revisions.

Best wishes, Anders 
Interactive comment 